\section{話 題}

米国の公衆衛生大学院における

産業医養成システムと日本の課題

一ハーバード公衆衛生大学院専門職

修士課程を通じて一

辻 洋志, 臼田 寛, 河野公一

大阪医科大学衛生学・公衆衛生学教室

抄録：米国の公衆衛生大学院における産業医養成システ ムと日本の課題一ハーバード公衆衛生大学院専門職修士 課程を通じて一：辻 洋志ほか. 大阪医科大学衛生学・ 公衆衛生学教室一目的：世界経済の急速なグローバル化 により労働者を取り巻く環境は大きく変化してきてい る.わが国の労働安全衛生制度は, 法律に準拠する形で 戦後一貫して充実強化されてきた。しかし，社会の変化 に伴い企業や労働者が産業医に求める内容も多様化し, 対応を迫られている. 対象と方法：米国は結果責任を伴 う自主対応型の労働安全衛生制度を取っている. 本稿で は体系的なトレーニングを行い，変化する社会の需要に 柔軟に応えることができる基礎を持つ産業医を養成す る, 米国の公衆衛生大学院のシステムを紹介する。結果 および考察 : 今後の日本の労働安全衛生の維持向上を模 索するに当たり，多様化する社会の需要に応えるには体 系的トレーニングによる個々の産業医や関連職の技能の 向上が不可欠であり，米国における公衆衛生大学院によ る産業医養成システムは一つの参考になると思われる。 （産衛誌 2011; 53: 33-38）

キーワード: Master of public health, Occupational physician, School of public health, Systematic training, United States

\section{I 、日米における労働安全衛生の動向}

近年，世界経済のグローバル化と国際競争の激化は労 働者を取り巻く環境に大きな変化を与えている。1990 年代以降，日本では低付加価值な産業や労働集約的な生 産工程は途上国へアウトソーシングされ，国内では高付 加価值なサービスや産業に特化する流れが急速に進んで いる。 それに伴い産業医が扱う労働者の健康問題も, 物

2010 年 9 月 26 日受付；2010年 11 月 29 日受理 J-STAGE 早期公開日：2011年 1 月 7 日 連絡先：辻 洋志 $=$ 5 569-8686 大阪府高柣市大学町 2-7 大阪医科大学衛生学 ·公衆衛生学教室 (e-mail : tsuji@post.harvard.edu)
理・化学要因への曝露に起因するものから, 過重労働や ストレスに伴う脳血管疾患や虚血性心疾患, メンタルヘ ルス不調へ移行している. また, 産業医は従来の年功序 列・終身雇用の制度下ではみられなかった雇用形態の多 様化といった社会構造の変化への対応も迫られている.

一般に労働安全衛生に関する制度には「自主対応型」 と「法律準拠型」があるといわれる．日本の制度は後者 に属し, 職場の労働安全衛生活動は法規によって詳細に 規定されている。定の従業員数に対して一律に産業医 の選任が義務付けられる制度はその一例である。これに 対し欧州諸国では，かつては日本のような法律準拠型が ほとんどであったものが，次第に結果責任を伴う自主対 応型への移行が行われている ${ }^{1)}$ 。米国では1970年に当 時の米国産業衛生専門家会議（ACGIH）の基準を参考 に, 実現可能性や経済への影響を鑑みた上での企業が満 たすべき労働安全衛生の最低基準を示した法律として労 働安全衛生法（OSHAct）が制定された。その後も経済 や産業の変化に応じて最低限の規定は追加されてきたも のの, 主には企業や専門家, 労働者それぞれの裁量に委 ね, 結果責任を伴う形で労㗢安全衛生が向上して来た。 自主対応型のシステムには, 急速に変化する現在の労働 環境において, 社会の需要に対して柔軟に対応できると いう利点がある。このシステムを可能にしている背景に は，労働安全衛生における体系的トレーニングを積んだ 専門家の育成がある。米国では公衆衛生大学院をベース に公衆衛生学専門職修士 (MPH： Master of Public Health）課程と実地研修を組み合わせた最低 2 年間の体 系的な産業医学科レジデンシープログラムがあり, 専門 家としての産業医の養成を行っている.

2009 年から 2010 年にかけて筆者（辻）は米国国務省 教育文化局および日本の文部科学省が合同で出資するフ ルブライトプログラムのもと, 米国のハーバード公衆衛 生大学院 (HSPH : Harvard School of Public Health) の $\mathrm{MPH}$ 課程（産業・環境衛生学）に在籍する機会を得 た。本稿では，HSPHの MPH 課程における実際のトレ ーニングを例に米国公衆衛生大学院による体系的な産業 医養成システムについて紹介する．本格的なグローバル 社会を迎え，変化する社会の需要に応えることができる 21 世紀型の産業医育成のための参考になれば幸いであ る.

\section{II. 米国における産業医の役割}

米国では産業医の選任が法律では定められていない. また日本で言う 5 管理, 月 1 回の職場巡視といった個別 企業に関わりなく，一律な産業医の職務も規定されてお らず, 産業医の業務内容は企業もしくは労働者の需要に より大きく異なる. 米国での産業医の業務形態は, 社会 からの需要を満たす形で大まかに企業をべースにした企 
業産業医 (Company Doctor)，病院やクリニックで臨床を ベースにしたクリニック・開業医 (Private Practitioner), 第三者機関として独立した活動を行うコンサルタント (Consultant) の3つに分けられる ${ }^{2)}$. 米国企業で主に 労働安全衛生活動を担っているのは, 産業看護職やイン ダストリアルハイジニスト（IH）と呼ばれる米国産業 衛生協会（ABIH）によって資格認定された専門家であ る。産業看護職や産業医は，企業では雇用主の判断に よって配置される。企業産業医は産業看護職や IH と連 携し, 企業内の労働安全衛生活動のマネジメントや高度 な専門的医学知識を要する職業病の診療, 健康管理, 適 所配置, 休業・職場復帰計画策定を主に行う ${ }^{3)}$.また, 健康・環境に関わる社内規則の整備，健康や生産性の評 価等を行うこともある．多くの場合，雇用主はこれら専 門家の配置により，最終的には従業員の健康予防による 生産性の向上や医療費の削減, 病気休職に伴う休業補償, 労災補償の削減といった経済効果を期待する。一方，米 国ではほとんどの大学病院や多くの教育病院において産 業医学科の専門クリニックが置かれており，郊外には産 業医学科を専門にした開業医も存在する。これらの産業 医は，臨床をべースに雇入時健康診断や薬物アルコール テスト，また法律によって義務付けられた健診業務や， 職業病診断・治療, 曝露や障害の評価, 職場復帰支援業 務等を行っている．最後に労働安全衛生問題を専門に相 談，指導を請け負うコンサルタントという業務形態があ る。労働安全衛生を専門にしたコンサルタントは，医師 だけでなくIHが行う場合も多く，コンサルタントだけ を専業としている医師は比較的少ない.IHは職場巡視 を通じて職場の有害要因の予測, 測定, 評価, コント ロールを行う知識や技術をもとに技術的相談業務を得意 とし，主に安全衛生を専門とするのに対し，医師のコン サルタントは安全も扱うがより保健衛生を専門にしてお り，保険会社，弁護士，企業の依頼によって職業病の診 断や労災補償に関連した業務起因性の医学的評価といっ た医学的相談業務と, 企業の依頼に応じて従業員の労働 安全衛生のガイドライン策定といったマネジメントに関 する相談業務を二大業務としている場合が多い2)。

米国には，2004年の報告で産業医学を専門に取り扱 う医師がフルタイム，パートタイムを合わせて約 10,000 人 ${ }^{4)}$ おり，2005年までに 3,518 人が後述する産業医学科 専門医を取得した ${ }^{2)}$ 。

\section{III. 米国公衆衛生大学院歴史・概要}

米国の公衆衛生大学院の歴史は，1916年のジョンズ・ ホプキンス大学公衆衛生大学院の設立に始まる. 当時ヨ ーロッパでは既にいくつかの公衆衛生大学院が存在して おり，米国でも病気の治療を基本に“Individual Health” を主眼に置く医学に対して，広がる環境污染に対する健
康被害の予防等, “Population Health”を扱う公衆衛生 の専門家を育成する必要性が叫ばれていた。元々米国の 公衆衛生大学院は医師を対象に考案された専門職大学院 であり, 公衆衛生学の知識や技術を習得した医師に, 公 衆衛生学専門職修士（MPH）の学位を与える場であっ た. その後, 公衆衛生の概念の広がりと社会的ニーズの 多様化から, 現在は医師だけでなく, 関連の学位, 実務 経験を有する者に MPHが授与されるようになった。 $\mathrm{MPH}$ 課程は大学院や入学者のバックグラウンドによっ て異なるが，通常 1 年ないし 2 年の就学期間が必要と なっている。ほとんどの $\mathrm{MPH}$ 課程では, 最初に公衆衛 生学全般を広く浅く学んだ上で, 後半に専門的内容を選 択して深く学ぶという形をとっている.

米国には，2010年 11 月現在で 44 の公衆衛生大学院が 公衆衛生教育協議会 (CEPH) に認可されている。2009 年度に認可されていた 43 の公衆衛生大学院の 2009 年度 入学者数は, 合計 10,251 人である ${ }^{5)}$.

\section{N. 米国の公衆衛生大学院における体系的産業医養成シ ステム}

1. 産業医学科レジデンシープログラムの概要 米国において産業医学 (Occupational Medicine) は 米国予防医学委員会 (ABPM) により専門医資格とし て認可されており，米国卒後研修認定委員会 (ACGME) の認可したレジデンシープログラムを受け，ABPMの 試験に合格することにより専門医資格が得られる。米国 において産業衛生に関連した医師の専門性を示す資格 は, この ABPM の認可する産業医学科専門医のみであ る.レジデンシープログラムとして ACGMEの認可を 得るためには, 大学院での修士課程と実地研修を合わせ， 最低 2 年以上の体系的トレーニングを提供する必要が ある ${ }^{6)}$ 。産業医学科レジデンシーは通常 2 年間あり， 1 年目は通常の MPH と同様に公衆衛生大学院で産業もし くは環境衛生学を専攻し, MPHに必要な単位を取得す る. 2 年目はプラクティカム (Practicum) と呼ばれる 実地研修が行われる．産業医学科専門医をはじめとする 産業衛生の専門家の組織である米国産業環境医学会 (ACOEM) は, 産業医学科専門医を増やし, 産業医学 科レジデンシープログラムに入る医師が経済的に不安定 にならないように，奨学金を支給する産業医奨学金基金 （OPSF）を設立している ${ }^{7)}$. さらに, 全米には大学を ベースとした労働安全衛生の教育研究拠点（ERC： Education and Research Centers）が17あり，NIOSH が 重点的に予算を配分し, 産業医の養成や, 生涯研修, 研 究を通じて各地域の労働安全衛生の向上を担っている ${ }^{8)}$.

2. MPH (Master of Public Health) 課程 ハーバード大学公衆衛生大学院（HSPH）を例に紹介 


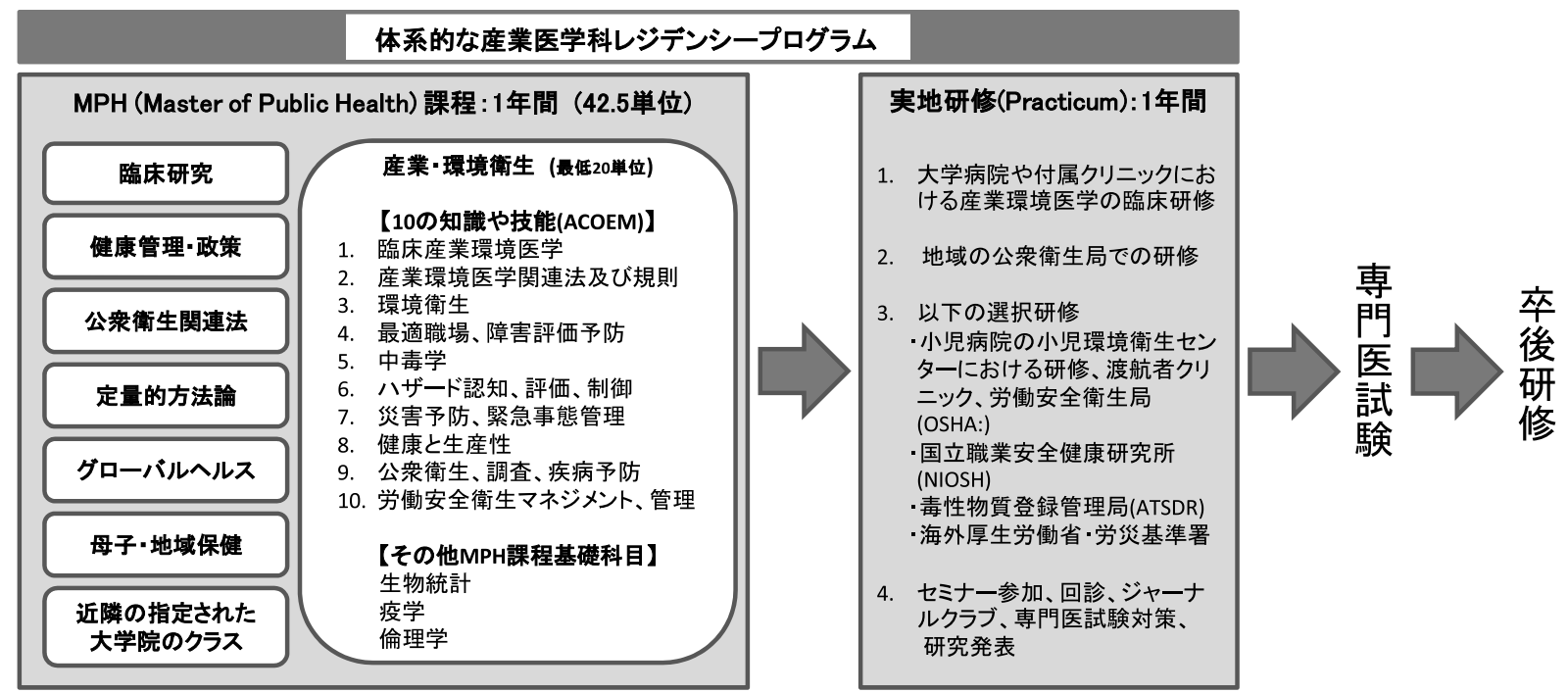

図 1. 米国における体系的な産業医学科レジデンシープログラム（ハーバードの例）.

する. HSPHの 2009 年度秋の入学者は 517 名で, CEPH の認可を受けた公衆衛生大学院の中で 3 番目に多い。そ のうち 357 名が $\mathrm{MPH}$ 課程である ${ }^{9)}$. MPH 課程はさらに キャリアに関連した7つの専攻に分かれており，産業・ 環境衛生学専攻はその一つである（図 1). HSPH は NIOSH の指定する労働安全衛生の教育研究拠点 (ERC) であり，またACGMEの認可した 2 年間の産業医学科 レジデンシープログラムを持ち，全米で最も充実したト レーニングシステムを有する大学の一つである. MPH 課程は合計 42.5 単位を必要とし, フルタイムの学生で あれば 9 月からの 9 ケ月半，もしくは 7 月からの 11 ケ月 間で MPH を取得する非常に凝縮されたコースとなって いる．産業・環境衛生学専攻では 20 単位はコアカリキュ ラムと呼ばれる必須，もしくは選択のクラスの中から単 位を取得する必要があり, 残りの 22.5 単位はHSPH内 のほかの専攻, もしくは医学, 経営学, 法律等ほかの八 ーバード大学院，近隣の指定された大学の関連したクラ スを選択して取ることができる。1クラス 110 分 $\times 2$ 回 /週の 2 ケ月間の受講で 2.5 単位として換算される. 各授業の長さや回数によって取得できる単位が異なるた め，42.5 単位満たすために取ることのできるクラスは異 なるが，産業・環境衛生学専攻であれば平均的に合計 15 前後のクラスを 1 年で取る場合が多い. HSPHの $\mathrm{MPH}$ 課程では, 前半は公衆衛生の基礎となる統計や疫 学のほか，それぞれの分野の入門的レベルのクラスが用 意されており, 後半はより専門的な内容に分かれて勉強 する.専門医を目指す産業医学科レジデンシーの医師は, 1 年目の MPH 課程において 42.5 単位を取得し, 2 年目 の実務研修に必要な知識を習得する. HSPHで提供され るクラスは将来専門医資格試験を受けるために必要な ACGMEの基準を満たす内容となっている。ACOEM
は産業医学科の専門医として期待された結果を生むため

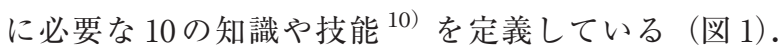
2009-2010年度において, HSPH の産業・環境衛生学専 攻ではこれら必要とされる知識および技能に対してそれ ぞれ最大 10 クラスあり，産業・環境衛生学専攻だけで 年間合計 76 クラス提供されている. HSPH内のほかの 専攻を含めると約 400 クラス ${ }^{11)}$ ，ハーバードや近隣の ほかの大学院のクラスを含めると，無数の中からクラス を選択することができる．また，クラスの内容や名称は 学生や社会の要望を取り入れる形で毎年変更がなされ る.さらに，学生の評価や受講者数が少ないとクラス自 体がその年度から廃止される一方，時代背景や学生の要 望に合わせて新しいクラスも毎年作りだされる。このよ うに，コアカリキュラムからの単位の取得による基礎の 確立と多様な選択肢によって，産業医を目指す医師は社 会の多様な需要に応えるために，それぞれの興味や，希 望する業務形態に合った技能を習得できるシステムと なっている。1年間の MPH課程におけるトレーニング は, 約 1 週間の期間で開催される日本医師会認定産業医 基礎研修会や産業医科大学において, 約 2 ケかけて集 中して行われる産業医学基本講座の内容を網羅し，大幅 に上回る内容となっている。 $\mathrm{MPH}$ 課程のいずれのクラ スにおいても, 講義と実践を想定したトレーニングがバ ランスよく組み合わされているのが特徵である.

\section{3. 実地研修 (Practicum)}

産業医学科レジデンシープログラムを持つほとんどの 公衆衛生大学院では, 一年目に MPH を所得した後, 2 年目にプラクティカム (Practicum) と呼ばれる実地研 修が行われる，内容は大学によって異なるが，HSPHを 例にすると 2 から 3 ケ月ごとに施設をローテーションし 
ながら予防，診断，治療，職業病のリハビリ，適所配 置・職場復帰，障害の評価，カウンセリング，労働安全 衛生教育, リスクコミュニケーション, 労働安全衛生計 画，管理，調査といった産業医活動を行うのに必要な具 体的技能を身につける (図 1). 産業医学科レジデンシー プログラムを採用する大学のほとんどにおいて，2年間 のレジデンシープログラムの間に学位論文が要求され, ローテーションと同時に必要な研究活動にも従事する. 学位論文は学術雑誌に揭載できるレベルである場合が多 い. HSPH では, Practicumの 1 年間外来研修や地域の 衛生局等の施設に打いて必要なトレーニングを行う ${ }^{12)}$ (図 1). 米国公衆衛生大学院は, 以上の上うな $\mathrm{MPH}$ 課 程と実地研修を合わせた最低 2 年間の体系的産業医学科 レジデンシープログラムにより, 労働安全衛生上の多様 な問題に柔軟に対処できる基礎を持った産業医を養成し ている.

\section{$\mathrm{V}$. 卒後研修}

ABPM は産業医学科の専門医試験を毎年 10 月頃に 行っている（図 1)。上述のレジデンシープログラムを 終えた医師，またはABPMの認定した公衆衛生・予防 医学，もしくは航空宇宙医学の専門医で，さらに 2 年以 上の産業医学に関連した研修歴のある医師に受験資格が ある ${ }^{13)}$ 。試験は午前と午後にそれぞれ 3 時間で 150 問の 選択問題からなるコア問題と専門問題に分かれて行われ る. コア問題は公衆衛生・予防医学の基本となる医学, 疫学, 統計, 法律・規制, システム, 産業医学や航空宇 宙学の基礎について問われ，専門問題は産業医学につい て専門的知識が問われる。専門医試験に合格して，はじ めて産業医学科専門医を標榜できるようになる。

ABPM は産業医学科の現在の専門医資格の認定更新 制度（MOC：Maintenance of Certification）を1998年 から導入して抢り，10年抒きに1）州の医師免許 2) 3 年抢きに最低 30 時間，合計 100 時間の ABPM 認証 MOC プログラムの受講および各回の理解度審査. さら に, 3 年扔きに最低 45 時間, 合計 150 時間の ACCME 認証生涯研修プログラム（CME）の受講．3）100問の マルチプルチョイスからなる認定更新試験。4）自己完 結式の技術・知識の自己評価㧍よび改善計画書の提出を 課している ${ }^{14)}$ 。一方，産業医のこれらの卒後研修を実 務面で担っているのが，産業環境医学の専門家の組織で ある ACOEM である。ACOEM の主な教育活動は 1 ）年 に一度のアメリカ産業医学学会 $(\mathrm{AOHC}), 2)$ 教育講演, 3）オンライン教育講演・教材，4）自己評価プログラム, 5）学会雑誌の発行，6）通信教育，7）データベースを利 用した自己学習, 8) 地方会・分科会の教育講演である ${ }^{15)}$. ACOEM はこれらの卒後教育の機会を通じて，MOCゃ $\mathrm{CME}$ といった産業医学科認定更新に必要なプログラム
の多くを実質的に担っている. 公衆衛生大学院はこうい った ACOEMの教育プログラムに講師を派遣し, 地域 の労働安全衛生の向上に寄与している.

\section{V. まとめ}

世界経済の急速なグローバル化により，労働者を取り 巻く環境は大きく変化してきている. わが国の労働安全 衛生制度は, 法律に準拠する形で戦後一貫して充実強化 されてきた。しかし，必ずしも法整備が追いついていな い現状の中で, 近年, 過労死やメンタルヘルス不調の増 加といった様々な問題が生じている。 また，雇用形態の 多様化といった社会構造の変化への対応も迫られてい る.グローバル化の進展に伴い, 今後とも企業は嬂烈な コスト競争にさらされることが予想される，その中で， 産業医として一律なサービスを提供するだけでは, 労働 安全衛生という活動自体が基準を満たすだけの活動とし て形骸化する恐れがある，労働者の健康を保持推進する という目標を達成するために，産業医は法律や基準のみ によらず企業や労働者，または社会の多様な需要に的確 に応えていかなくてはならない，そのためには専門家の 養成が必須である. 米国では, 公衆衛生大学院をべース にMPH 課程と実地研修を組み合わせた体系的産業医科 レジデンシープログラムにより, 労働安全衛生上の多様 な問題に柔軟に対処できる基礎を持った産業医を養成し ている.

現在の日本に扔ける産業医の専門性を示す制度の中 で，体系的トレーニングと試験の両方を制度の上で課し ているのは, 産業衛生学会の産業衛生専門医の資格のみ である。この専門医は，受験資格として実質的に約 300 時間に相当する産業医学基礎研修を修了していることが 条件であり, 産業医科大学に揸いて約 2 ケ月かけて集中 して行われる産業医学基本講座修了者や, 海外の MPH 取得者が該当する。しかし，日本には上記基本講座のほ かに米国の産業医学科レジデンシーの MPH 課程に相当 するような体系的講座が無いため, 産業医を目指す全国 の医師が受講することは難しく, 実質的には指導医の承 認のもとに自己学習が認められている ${ }^{16)}$. 一方, 米国 の産業医学科レジデンシーの実地研修に相当する実務研 修については，日本では米国のように誰でも受けること ができるような体系的な実務研修を組む施設は存在しな い.日本各地では日本産業衛生学会の学術総会や産業 医・産業看護全国協議会, 各地方会における活動, 産業 医部会が主催するワークショップや産業医プロフェショ ナルコース, 医師会の主催する産業医認定研修会など, それぞれの機関が産業医の教育研修を行っている。しか し, 生涯研修としての目的が強く, 現状では日本におい て米国の産業医学科レジデンシーのような体系的な産業 医の養成は行われていない。全米には，上述のように大 
学をべースとした労働安全衛生の教育研究拠点（ERC） が 17 あ，産業医の養成や生涯研修の拠点を担ってい る.これらの拠点へは米国疾病管理・予防センター （CDC）の管轄である NIOSHが重点的に予算を配分し， 地域の労働安全衛生の向上に寄与している.日本におい ても全国各地の大学をベースにした教育研修のセンター 化や，各地に設立の動きがある公衆衛生大学院を利用し た体系的トレーニングの体制構築が急務である。このた めには，米国の例のように研究予算の配分など国の協力 も必要である．また，修学者が経済的に不安定にならな いように奨学金などの修学支援措置も同時に整備する必 要がある.

本稿では産業医学科レジデンシーとして体系的なトレ ーニングを積み, 変化する社会の需要に柔軟に応えるこ とができる，専門的技能を持った産業医を養成する米国 の公衆衛生大学院のシステムを紹介した。今後, 日本に おいて少子高齢化に伴い労働人口の減少が見込まれるな かで，社会を支える労働者の健康を守ることは国家の発 展にとって重要な課題である. 今後の日本の労働安全衛 生の維持向上を模索するに当たり, 多様化する社会の需 要に応えるには個々の産業医や関連職の技能の向上が不 可欠であり，米国における公衆衛生大学院による産業医 養成システムは一つの参考になると思われる。

\section{文献}

1）矢野栄二, 行山 康, 大山高令, ほか. 産業保健活動の国 際比較. 平成 11 年度調查研究. 東京: 公益財団法人労働 問題リサーチセンター, 1999.

2) LaDou J. The Practice of Occupational Medicine. In: JaDou J. Current Occupational \& Environmental Medicine: Fourth Edition. Sykesville: McGraw-Hill Medical, 2006: $1-4$.

3) ACOEM Careers in Occupational and Environmental Medicine. [Online]. 2010 [cited 2010 Nov 28]; Available from: URL: http://www.acoem.org/guidelines.aspx?id=992

4) Orris P. Fifty Years of hope and concern for the future of occupational medicine. J Occup Environ Med 2004; 46:
515.

5) Association of Schools of Public Health. New Enrollments by School and Gender. Annual Data Report 2009; 2009: 31.

6) ACGME. ACGME Program Requirements for Graduate Medical Education in Preventive Medicine. [Online]. 2010 [cited 2010 Nov 28]; Available from: URL: http://www. acgme.org/acWebsite/downloads/RRC_progReq/380pr07 012007.pdf

7) OPSF. Occupational Physicians Scholarship Fund. [Online]. 2010 [cited 2010 Nov 28]; Available from: URL: http://www.opsf.org

8) NIOSH. 17 university-based Education and Research Centers (ERC). [Online]. 2010 [cited 2010 Nov 28]; Available from: URL: http://niosh-erc.org/courses/locator.shtml

9) Harvard School of Public Health. HSPH Facts 2010; 2010: $1-20$.

10) ACOEM Competencies-2008. [Online]. 2008 [cited 2010 Nov 28]; Available from: URL: http://www.acoem.org/ uploadedFiles/Publications/OEM_Competencies/ACOEM \%20OEM\%20COMPETENCIES.pdf

11) Harvard School of Public Health. Catalog 2009-2010; 2009: 13-5.

12) Harvard School of Public Health. The Harvard Occupational \& Environmental Medicine Residency (OEMR). [Online]. 2009 [cited 2010 Nov 28]; Available from: URL: http://www.hsph.harvard.edu/research/oemr/ about-us/

13) ABPM. Certification Requirements. [Online]. 2010 [cited 2010 Nov 28]; Available from: URL https://www.theabpm. org/requirements.cfm\#Special

14) ABPM. ABPM Maintenance of Certification (MOC) Online Center. [Online]. 2010 [cited 2010 Nov 28]; Available from: URL: https://www.theabpm.org/moc/ requirements.cfm\#part2

15) ACOEM. CME Mission Statement. [Online]. 2010 [cited 2010 Nov 28]; Available from: URL: http://www.acoem. org/cmemission.aspx

16）大久保利晃, 専門医制度一設置経緯及び設置後 12 年間の 推移. 産衛誌 2004; 46: 89-97. 


\title{
Systematic Training for Occupational Physicians in Schools of Public Health in the US and Its Application to Japan's System - Master of Public Health Program at Harvard School of Public Health-
}

\author{
Hiroshi TsuJI, Kan UsudA and Koichi KonO
}

Department of Hygiene and Public Health, Osaka Medical College, 2-7 Daigakumachi, Takatsuki City, Osaka 569-8686, Japan

\begin{abstract}
Objectives and Results: Globalization has progressed tremendously resulting in far-reaching changes in the work environment. In Japan, occupational health and safety (OSH) activities are performed under and improved by regulations. However, this system is not likely to satisfy the unceasing diversification of social demand for OSH in recent years. The US adopts a self-imposed OSH system with responsibility carried by employers under a system of minimum regulation. This paper introduces the systematic training for occupational physicians
\end{abstract}

in schools of public health in the US, which is creating a base of OSH professionals who can meet social demand. Discussion: To satisfy the diverse demand for recent $\mathrm{OSH}$, it is essential to improve the basic skills of occupational physicians and other OSH professionals by offering systematic training in Japan. Some examples of systematic training for occupational physicians in schools of public health in the US are discussed with the goal of improving Japan's future OSH.

(San Ei Shi 2011; 53: 33-38) 